\title{
Murderous Ritual versus Devotional Custom: The Rhetoric and Ritual of Sati and Women's Subjectivity in Amitav Ghosh's Sea of Poppies
}

\section{Barnali Sarkar}

English Language and Culture, Philosophical Faculty, University of Eastern Finland, 80101 Joensuu, Finland; E-Mail: barnali.sarkar@uef.fi; Tel: +358-456-316-644

Received: 6 May 2014; in revised form: 6 June 2014 / Accepted: 16 June 2014 /

Published: 27 June 2014

\begin{abstract}
The representation of the practice of sati, the immolation of widows on their husbands' funeral pyre, has garnered interest for long from postcolonial and feminist discourses among others. While advocates of Western modernity perceive sati as a murderous ritual, the proponents of orthodox Hinduism, on the contrary, claim sati to be a courageous cult of "wifely devotion". In both bigoted beliefs, as poststructuralists observe, women largely appear as “mute objects". Amitav Ghosh's Sea of Poppies (2008) brilliantly sidelines the conundrum of polarizing representation of sati along the East-West axis and reflects instead the subjective experience of women as sati. The article examines how the rhetoric and ritual of sati in the novel enable marginalized women to acquire consciousness of their subjectivity in a colonized society. To this end, the paper analyzes deconstructive readings of sati, such as by Gayatri Spivak, and explores the way the novel uses religion as a ploy, which, instead of perpetrating violence, confers a subjective entity on the sati that can even subvert the constrictive norms of a colonized society.
\end{abstract}

Keywords: Sati; Sea of Poppies; women's subjectivity; Gayatri Spivak; colonized society; religion

\section{Introduction}

The custom of sati, the practice of immolation of widows on their husbands' funeral pyre, has been at the center of debate over the representation of the East in texts and paintings by the West. Although most recorded incidents of sati can be traced in documents by British officials, who were often present at such occurrences to deter them or dissuade the would-be satis, foreign navigators, missionaries, 
travelers and even some native intellectuals could vouch for the occurrences of sati as a religious practice. Though the anti-sati law had been promulgated in 1829, late-twentieth-century India witnessed a resurgence of interest in the custom of sati with the immolation of Roop Kanwar [1,2], a Rajput widow, in 1987 in the state of Rajasthan, which was notable for its different spiritual interpretation of the custom from that prevalent in other parts of India [3]. While such recurrences only confirm the West's and even Indian feminists' perception of sati as a popular murderous ceremony which has acceptance in Indian society even today, parts of East and/or orthodox Hinduism, on the contrary, maintain the argument that sati is a courageous cult of "wifely devotion" as women "voluntarily" want to make themselves sati with no religious or social force exerted upon them ([4], p. 8). One way out of this morass, as contemporary critics such as Francine Pickup and others [5] have suggested, is to research into the politics behind sati. Another popular convenient way is to decode ancient Hindu religious texts and parts of historical texts such as The Mahabharata [6] in search of supportive textual dictates. Though these approaches are commendable in tracing the roots of sati as embedded in the fabric of Indian society, poststructuralists argue that the women who undertake the ritual of sati largely appear as "mute objects" in most discourses on the practice ([7], p. 10).

Amitav Ghosh's Sea of Poppies (2008), however, brilliantly sidelines the conundrum of polarizing representation of sati along the East-West axis and focuses instead on the subjective experience of women as sati. This article aims to show that, in contrast to the contentious perceptions of sati both as a murderous ritual and a devotional custom, the rhetoric and ritual of sati in the novel enable marginalized women to acquire consciousness of their subjectivity in a colonized society. Therefore, the article is concerned with the subjectivity of the woman who undergoes the cult, an issue which often remains unaddressed in most discourses on sati [8]. The role of religion will also be analyzed in the process and the article will examine the ways the novel uses religion as a ploy which, instead of perpetrating violence on the sati, confers a subjective entity on her that can even subvert the constrictive norms of a colonized society. However, in doing so, the article by no means claims that Ghosh attempts to reestablish or advocate sati as a justifiable practice in Indian society in his revisiting the colonial past of India. Rather, the essay claims to show how the text's representation of sati departs from traditional explanations of sati as an entirely religious practice since the novel, instead of focusing on the rite itself, emphasizes the subjective consciousness of the woman who undertakes the rite. To this end, the article relies principally on deconstructive readings of Hindu religious texts such as those proposed by Gayatri Spivak and Sakuntala Narasimhan. It will also address critiques of western modernity such as by Ashis Nandy and Lata Mani who argue that sati has mostly been misrepresented by the West/western modernity for its various political motives with the usual tendency to generalize about the East and its culture.

\section{Discourses-Counter Discourses and the Problem of Representing Sati}

With this aim in view, it appears pertinent to begin with an account of the factors that have shaped the terrain of debates on sati since it will aid in locating the aims of the article in the existing body of discourses. The contentiousness of the practice of sati is borne out by a number of representational polarities: tradition/modernity, legality/illegality, and voluntariness/involuntariness to name a few. For many Indian feminists and liberals, sati stands for a "fundamental infringement of the widow's human 
rights" and it symbolizes only violence against Hindu women ([9], p. 783). For those who support sati on the basis of its being an exertion of a Hindu widow's right to self-immolate, as Andrea Major cites critic Madhu Kishwar's view on the rights of the sati, such religious observances represent the triumph of traditional Indian values over the modern Western principles propagated by colonialism [9]. The adherents of "voluntary" sati even connect it to "a glorious Hindu past, the 'traditions' of which are often being actively reinvigorated in the rhetoric of an aggressive and exclusivist Hindu nationalism (Hindutva)" ([9], p. 784). However, for the question of sati's legality, it is often claimed that the East India Company declared sati to be an inherently religious practice and even announced it legal under certain circumstances ([10], pp. 18-21). Moreover, quite contrary to the generalized perception that the custom of sati received only vilification from the West, Major asserts that the West considered the act as worthy of admiration as well [3]. Nonetheless, the discourse on sati, at the crossroads of both traditional and modern representational crises, has never ceased to excite both the worlds, the West and the East, since, as critics such as Paul B. Courtright view, the act is caught between "two incommensurate views of reality":

On the one side is a religious view in which lives travel from incarnation to incarnation, and self-sacrificial actions have effects that go beyond the immediate circumstances in which they are produced. On the other side is a modern view according to which individuals "make themselves" in social environments that are more or less hospitable to a person's self-fulfillment. In the former view, sati is the ideal heroic and sacred action; in the latter, a paradigm of powerlessness ([11], p. 29).

However, critic and thinker Nandy believes that it is the Western and modern-Westernized Indians' vituperative reaction to sati and Hinduism that has created the present ambivalence about sati and has also resulted in "strange anomalies in Indian public life" ([12], p. 133). Therefore, the most popular practice of castigating Hindu religious texts in order to bolster the view that Hinduism has its root in criminality as reflected in the murder of women in the name of religious practices does not lead to the reality of sati $[12,13]$. Nandini Bhattacharyya-Panda has traced the roots of sati as a brahmanical social order in Bengal to a treatise called Súddhitattva (means "discourses of purification"), which strongly dealt with the moral and virtuous notions of sati and hardly mentioned anything about the act's involvement with religion, inheritance and property rights of widows ([13], p. 397). She argues that it is the colonial rulers who transformed its meaning from purification into "duty", "loyalty" and "fidelity" at the time of its inclusion within the colonial codes on Hindu civil and personal law ([13], p. 398). It is also claimed that sati's present form of violence is a creation of Western colonialism and its modernity [12]. Nandy shows how the original, traditional, and mythological meanings of sati, where "the idea was associated with convictions about the sacred and magical powers of women" and their superiority over patriarchy, received economic motive, which emphasized women's "productive capacity" and "market value", with the arrival of colonialism ([12], pp. 139-41). The popularity of sati even in twentieth-century India as an "auspicious opportunity to create wealth" only testifies to the continuation of such economic interests ([14], p. 156). In a similar vein, it is often argued that it is the misogynist colonial attitude to Hindu women which came to light with the codification of Hindu law and its customs that denied women rights to their property and this policy was hardly related to the rules of Smritis [15]. However, Spivak in her seminal essay "Can the Subaltern Speak?" shifts the 
blame on to the representation of sati in texts. She argues that while much attention has been allowed to settle on the practice of sati as a blot on Indian culture, few attempts have been made to unearth the vast body of misogynistic ideology knitted into the fabric of Indian society, and Indian women, in the process, who had to go through such customs, are often represented as objects of study ([16], pp. 302-03). This often creates the viewers'/readers' ambivalence towards Indian women's perception of sati and therefore the crux of the crisis of representing Indian women as sati resides in the fact that "[i]f she resisted, she was considered a victim of Hindu male barbarity. If she appeared to consent, she was seen to be a victim of religion" ([8], p. 36). A vast body of studies on sati, as it happens, views sati "as the privileged signifier of either the devoted and chaste, or the oppressed and victimized Indian (or sometimes even 'third world') woman" ([17], p. 209).

Therefore, it appears that the dilemma of representing sati results from a set of conflicting issues that dovetail together to mar both the reality behind sati and the clarity of its expression: first, the subjects of the practice of sati are largely objectified and their experiences are heeded only to the extent of determining whether their participations in the custom are voluntary or involuntary, and secondly, it is the religion that has always been identified in the cult of sati as the core of the violence perpetrated against women $[8,10]$. However, the necessity to incorporate women's experiences as sati into the mainstream discussion on the oppressed has been crucial to many scholarships that aim to recover "the histories and perspectives of marginalised people" [18]. Amitav Ghosh's Sea of Poppies (2008) reflects such tendencies of revisiting the past of the colonial era and rewriting the history of marginalization hemmed in by Indian society, its customs and the British colonial aggression on its land for the cultivation of poppies. In most of his writings Ghosh has revealed his obsession with "the highly individual, often contested and marginalised histories, such as those of refugees, Indian sepoys under the British Raj [...] and voiceless women", which often imparts an aura of "global, ecumenical perspective" to his novels ([19], p. xv). Nonetheless, Ghosh's delineation of sati as part of his agenda of addressing "marginalised histories" in Sea of Poppies demands particular attention in its explication of an alternative reality of sati that not only intends to resolve the binary opposition between voluntary and involuntary sati in reflecting the subsequent effects of the custom on the individual who goes through it but also disabuses the generalized perception of sati, maintained by both the East and the West, as an invariably religious act. The following sections will highlight such contrasting realities in the novel and contextualize the protagonist's marginalization that ultimately encourages her decision to be a sati.

\section{The Background of Sati and the Contrasting Reality}

The narrative of Sea of Poppies captures the essence of early-nineteenth-century-India, combining a number of stories of a group of marginalized Indians whose lives revolve around a slave ship that aims to transport them from India to Mauritius as indentured laborers. A significant part of the novel remains occupied with the story of a marginalized woman, Deeti, the wife of an impotent, opium-addicted and uncaring ex-sepoy in the village of Ghazipur, east of Benares, India. She goes through the rituals of sati after her aged husband's death, but a low caste man rescues her. She starts a new life with her rescuer and finally they board the Ibis, the slave ship, and set sail for Mauritius. The life, however, that Deeti is shown to live is that of a shadow, an object whose value is judged only by 
its "market value" and "productive capacity" ([12], pp. 139-41). Thus she recalls in a flashback how she was drugged and raped on the wedding night by her brother-in-law, which was approved by the in-laws and even by her husband since the family of her husband knew about her husband's impotency and therefore it was the brother who had the duty of impregnating the new bride whose task should only be, as assumed by the family, to give birth to a male child. Narasimhan informs that Indian patriarchal values, which would decide women's goals in life, nourished similar beliefs that "marriage and motherhood (begetting sons, in particular)" should be the only goals for women ([4], p. 47).

It is no surprise then that, when Deeti's impotent, aged, uncaring and opium-addicted husband dies, this same patriarchal ideology which judges women only according to their "productive capacity" is overjoyed at her proposal of immolating herself on the pyre of her dead husband and therefore performing the rites of sati, since it cherishes the sentiment that women's existence should lose "its rationale once the husband was dead" ([4], p. 51). However, what such tyrannous values in this context fail to notice, which also constitutes the pivot of the argument of the article, is that Deeti's attempt to become a sati is not motivated by her desire to prove her purity or to bring honor to her family, as, according to Hindu religious regulations, should be the case for the practice of sati $[4,16]$. Nor does she take the commandment of religion as her own will in her decision to mount the funeral pyre of her husband as has often been claimed by the West $[8,16]$. Instead of nurturing the idea of sporting with her husband in heaven after her immolation ([16], p. 303), as traditional Hindu scriptures preach [20], Deeti decides to sacrifice her body in the funeral pyre to escape the skewed reality that threatens her in the form of frequent sexual harassments and fear of forceful accumulation of her land and property by her brother-in law after her husband's death. According to Spivak when, at a certain point in Indian history, women were bestowed the legal right of a property holder, the custom of sati became more prevalent and was strongly associated with the concept of ideal womanhood ([16], p. 303). Nevertheless, such economic motives were often camouflaged with the assertion that sati is an instance of "tremendous courage by women who cared more for their cherished ideal of wifely devotion than for their lives", which also encourages the admiration and veneration of those women as deities soon after their immolations ([4], p. 8). However, many historians have asserted that some Hindu laws, such as the Dayabhaga system, denied women land rights, both of their fathers' and their husbands', which often created ambiguity in their class status and rendered them "incomplete caste and class subjects" ([21], p. 19). Needless to say, however, being the mother of a girl child [22-24] Deeti has no chance of owning her husband's land after his death unless she accepts her brother-in-law's frequent sexual violence as the norm.

\section{Sati and Her Religious Creed}

Since the debate over sati resides in the question of "the widow's choice" or desire ([17], p. 215), Deeti's perception of religion and her religious creed appear to be the focal point in determining what sati means to the woman who undertakes it. In the very beginning of the novel, Deeti is shown to be flummoxed by the apparition of the slave ship, Ibis, which also finds its place in her personal pantheon. Other than the statues of widely-revered gods, her pantheon contains a wide variety of strange objects that serve as tokens of reverence for her, such as her father's wooden clogs, charcoal portraits of dead brothers and sisters as well as of a few relatives who are still alive ([25], p. 9). Deeti 
even draws the image of the vessel on a mango leaf and places it in her shrine. When asked about the reasons behind such unusual action by her daughter, Deeti expresses the conviction that her intuitive faith is stronger than any other faiths she possesses:

The child could not understand why a ship should find a place in the family pantheon.

But why? she said. I don't know, said Deeti, for she too was puzzled by the sureness of her intuition: I just know that it must be there; and not just the ship, but also many of those who are in it; they too must be on the walls of our puja room ([25], p. 9).

In the beginning itself, therefore, it is made evident that the slave ship and the marginalized indentured laborers that the ship carries hold such importance for Deeti in the form of the apparition that they manage to secure their place besides Hindu gods in Deeti's shrine. Moreover, she even maintains a shrine on a beam of the ship, painting images of her daughter, which a devout follower of Hinduism could hardly imagine in nineteenth-century India ([25], p. 394). Therefore, it appears that Deeti's religious view is not entirely hazed with the traditional Hindu ritualistic norms, which prioritize the worshiping of gods over any other living/non-living objects associated with ephemeral human life. She cannot, therefore, be claimed as a strict follower of Hindu religious strictures. Consequently, it can be argued that her act of self-immolation should be viewed as a form of suicide. In fact, Anand A Yang has interpreted sati as a ritual suicide that provides an option for widows to terminate their real "after life" of certain misery at the hands of their in-laws who consider her only a hazard after her husband's death ([7], pp. 26-27). However, the suicide that Deeti attempts to commit as sati is sharply different from the suicides that Indian women, as the West perceives, intend to commit for religion. It differs from the suicides and self-sacrifices which are called "ātmaghāta" and "ātmadāna" which are usually performed, as Hinduism views, for the well-being of society and/or family ([16], p. 299). In the context, therefore, Deeti's innermost feelings or "innate disposition", which is originally called "bhavā of the sati", should be taken into account ([26], pp. 19-20). More than "unconditional love" and "absolute fidelity" which foreground the bhava of self-sacrifice of women, Deeti's bhavā of self-sacrifice is governed by her desire to preserve her own virtue. Therefore, she decides in favor of religious death which, contrary to natural death, would at least bring her honor and glory in promoting her from a worthless object to a deity, venerated by all, men and women alike. Therefore, her choice of sati in preference to a life of an object appears to be expedient, in compliance with her penchant for a subjective entity and social admiration.

\section{The Ideology of Subjugation and the Celebration of Self-Sacrifice}

Therefore, it can be extrapolated that it is the patriarchal stranglehold on society which, as a byword for religion, conditions Deeti's approach to the fire. Critics concerned with the violence against women in India have identified patriarchy as "one of the underlying causes of violence against women in India" since it has ubiquitous influence on every sphere of Indian society including religion ([22], p. 1052). However, the novel exemplifies the way Indian patriarchy justifies its ulterior misogynist ideology of subjugation through the portrayal of the character of Chandan Singh, Deeti's brother-in-law, who, as a prototype of patriarchal supremacy, is resolute in proclaiming his own distasteful opinion of Deeti and women in general. When Deeti's husband is on his death bed, Chandan Singh, who has 
scared Deeti with frequent sexual harassments, starts reasoning with her, though quite brazenly, on the need of her having a son by him. However, Ghosh suggests that this threatened attack of rape by him is actually an exchange of diverging opinions: "The assault, when it came, was not physical, but rather an admission and an argument" ([25], p. 157). While Deeti proclaims that she prefers to be a "sati" to a "keep", Chandan Singh expresses the belief, which religion and imperialist patriarchy have instilled into him, that a woman's body loses its purity if she is violated, referring to the incident of Deeti's violation on her wedding day, though here it is the speaker himself who has been the violator:

Do you think it's easy for a worthless woman like you to die as a sati? Have you forgotten that your body ceased to be pure on the day of your wedding? [...] All the more reason then, she said, to burn it in the fire. And it will be easier than to live as you say ([25], p.158).

Therefore, instead of viewing sati as a sacred ceremony of sacrificing a woman's "pure" body to the fire, Deeti, perceives sati as a means to an end, and the end for her is to destroy her impure body and thus to prevent its further defilements. However, the preservation of the purity of Hindu women's body was regarded as a prerequisite for the observance of all sorts of customs and rituals of Hinduism [21]. Historians often claim that the rhetoric of Hindu nationalism after 1857 not only made gender discrimination on the basis of education and property rights but also connected the ideology of national purity with the body of the Hindu woman, which was "moulded from infancy by a shastric regimen of non-consensual, indissoluble, infant marriage, and by iron laws of chastity, austere widowhood and a supposedly proven capacity for self-immolation" ([21], p. 143). However, it is Deeti, who herself proposes to be a sati and decides to forego her life to preserve her chastity and escape the reality. Hence, she asserts "I will burn on my husband's pyre rather than give myself to you [Chandan Singh]" ([25], p. 158). However, such attempts often lead to the violation of original rules and rhetoric of sati since "[n]o woman was allowed to burn who had been unfaithful to her husband [...]. The sati was to be in a state of ritual perfection and purity. By burning [...] she demonstrated that her steadfast devotion had never wavered" ([27], p. 467). Nonetheless, Deeti seems to possess neither any faithfulness towards her dead husband nor any predilections for the ritualistic perfection of the rite. Besides, it is expected that the woman who decides to be a sati should express so by her spontaneous vow or vrat which makes her a sativrata and bestows a supernatural power on her ([14], p. $159 ;[28,29])$. Deeti's resolution to be a sati, however, is not followed by any vrat or vow that can transform her into a sativrata. Rather, she nurtures a strong impulse of eluding the excruciating hazards of her teenage widowhood which ultimately motivates her to embrace the rituals of sati [30]. Therefore, the most celebrated devotional custom of sati holds no religious or social significance to Deeti since it appears only as a religious ploy to her that can enable her to escape the painful circumstances. In that sense, she is literally a "pure" and true sati, who wants to preserve her chastity and dignity in the face of a threatened rape, and is therefore a sati for herself.

However, Deeti's resolution to be a sati, an act of proving women's chastity and devotion towards their husband, causes a huge sensation all over Ghazipur [31]. Incidentally, most of the paintings and texts on sati usually portray the image of a burning woman applauded and encumbered by a huge crowd. Critics who verify the popularity of the cult claim that such practices draw wide public interest and encouragement in the form of celebration [32]. Narasimhan shows how a temple built on the (sacred) place of the immolation of a widow in the state of Rajasthan in India some 700 years ago can 
draw an annual income of around twenty lakh rupees even today and it is endorsed by the leading political parties and a part of the government ([4], p. 11). Radha Kumar has also argued that such events clearly reveal "the gruesome materialism of a society which permitted the production of 'sacrifice' for profit" ([33], p. 175). In a similar vein, Ghosh depicts the way the very act of sati is encouraged in a colonized and rural society; the large size of the funeral pyre, where the sati is destined to be held, and the grandeur of the entire situation provide the practice of sati with an aura of celebration and festivity: "Not only was it [the pyre] far larger than was necessary for the cremation of a single man, it was surrounded by a profusion of offerings and objects, as if it were being readied for some larger purpose" ([25], p. 176).

Nonetheless, Deeti is rescued from the funeral fire by the low-caste ox-man who, despite being a man of immense physical strength, has been subjected to humiliation by upper-caste Hindus. It would be appropriate to study the circumstances of Deeti's rescue by a native man or the saving of a "brown woman" from the fire by a "brown [native] man" in the context of Spivak's disquisition on the West's perception of the abolition of the practice of sati. Spivak argues that the outlawing of the practice of sati has more often than not been regarded as a case of "[w]hite men saving brown women from brown men" ([16], p. 297). Many recent studies on the representations of the cult of sati in paintings, often by Baptist missionaries, also attest to the West's political agendas in depicting Indian women, burning in the flames, as appealing to "British humanity" to save them from the cruelty of brown men ([34], pp. 223-24). The custom of sati, however, provided an excellent opportunity for the colonial rulers to prove the incivility and uncouthness of Hindus and to demonstrate, therefore, the necessity to civilize them through its abolition ([24], p. 500). As a result, it was believed that the act of saving brown women from brown men would help the colonizer establish a "good society" ([16], p. 298, emphasis original, [35]). Spivak, therefore, argues that there is hardly any difference between the assertion of the brown men's patriarchal ideology which viewed the sati, the woman, as an object who should be sacrificed for the well-being of society, and the white men's imperial patriarchal strategies which regarded the sati as the "object of protection" ([16], p. 299, emphasis original). The only difference lies in the proclaimed humanity, which the West itself claimed to possess [36] in sharp contrast to the East, which was alleged to be the domain of treacherous culture. Therefore, Deeti's rescue by Kalua, a brown, lower caste man, who himself as a subaltern bears the brunt of Hindu caste system, clearly subverts the established perception of the West which considers the prevention of sati only in terms of colonial intervention. Moreover, Deeti's escape from the pyre with a low caste man negates not only the generalized conviction that ritualistic practices such as sati were pervasive and entrenched in Indian society but also the entire hierarchical system of caste actively encouraged by Hinduism. Narasimhan, in her search for oppressive traits against women in Hindu religious texts, has found that in some religious texts such as Satapatha Brahmana "[w]omen, shudra (the lowest of the four castes), dog and crow embody untruth, sin and darkness" which also has its manifestations in many earlier works of literature where women were often bracketed with the shudras ([4], pp. 44-45). Therefore, the brouhaha that follows afterwards over her escape is in compliance with the religious belief viewing the entire incident as a lower caste man's or a shudra's intervention in a holy upper caste religious practice and the upper caste woman's participation in the crime [37]. Since sati was associated with social status, the "practice was important for its religious and social meaning, rather than for its actual prevalence" ([27], p. 466). However, it appears that more than becoming ashamed of not being able to 
perpetrate the act of sati, the in-laws of Deeti become obsessed with her rescue by a low caste man and her decision to be saved. The entire incident, therefore, is interpreted as an offence against social mores with disloyalty and betrayal at its center.

\section{Reversals of Rules}

For the representation of women's self-will in performing the rituals of sati, it has been argued that Indian women are forced to accept religious subjugation as their own will and therefore perform the practice of sati to prove their good womanhood [4]. However, Deeti, though religious, does not appear as a woman repentant for her escape. She does not seem to be burdened with a sense of guilt over her escape from the fire. Instead of being remorseful of not being able to die and be a sati, as should be the case for a religious sati, she feels a joy within and starts a new life with the love of the ox-man, her savior:

Even then she did not feel herself to be living in the same sense as before: a curious feeling, of joy mixed with resignation, crept into her heart, for it was as if she really had died and been delivered betimes in rebirth, to her next life: she had shed the body of the old Deeti, with the burden of its karma [...] she could hear the whispering of the earth and the river, and they were saying to her that she was alive, alive and suddenly it was as if her body was awake to the world as it had never been before, flowing like the river's waves, and as open and fecund as the reed-covered bank ([25], pp. 178-79).

Therefore, here the practice of sati appears as a process, through which a woman's vision of her life changes. The same Deeti who would always cover her face to avoid Kalua's gaze and maintain distance to avoid his touch as a low caste man now comes to realize the insignificance of such caste divisions in society only after visualizing her own plight at the hands of her relatives and being saved from the fire. When Deeti realizes that she has been saved, she immediately brushes off her old past ties with the social and cultural norms, decides to get married to Kalua even without awaiting his consent and sets out to make arrangements for a secret wedding. Her intention of refuting the constrictive religious and social mores through her marriage and decision to lead a conjugal life is a symbolic reversal of traditional Hindu religious rules. Narasimhan informs that most of the Hindu religious texts including srutis and smritis are silent on the customs of sati to be followed by a widow, though they have specific injunctions inscribed for a widow to follow after her husband's death ([4], p. 23). Spivak, however, refers to the most celebrated four ages, brahmacarya (celibacy especially prior to marriage), garhasthya (married life), vanaprastha ("forest life") and samnyasa ("laying aside"), in the regulative norms of Brahmanism in order to highlight the process of "ideological formation" of women as "sexed objects" in mythological and religious texts ([16], p. 302). These stages and their significance to both men and women, as Spivak questions, mostly remain unexamined, whereas only the practice of sati, a part of the whole system of misogyny, has received severe criticism both from the East and the West ([16], p. 302). Spivak argues that while the man, whether a husband or a widower, passes through all these phases in his life, the woman is denied the "mature celibacy and renunciation" of the final phase: 
The woman as wife is indispensable for garhasthya, or householdership, and may accompany her husband into forest life. She has no access (according to Brahmanical sanction) to the final celibacy of asceticism, or samnyasa. The woman as widow, by the general law of sacred doctrine, must regress to an anteriority transformed into stasis ([16], p. 302).

However, for Deeti, an upper caste widow, her joy at her new life and remarriage signify a complete reversal of such regulative norms of widowhood. When Deeti's impotent husband was alive she led a life of celibacy, though it was meant to be a garhasthya life. Moreover, when her husband dies, the same patriarchy which rejoices at Deeti's decision to be a sati, does not allow her to live a life of brahmacarya or celibacy or even a life in stasis as a proper widow. Rather, it views Deeti's life as insignificant after her husband's death and proposes obnoxious solutions, in the form of sexual harassments, for the rest of her life. Therefore, the religious rules of social order upheld by Hinduism appear to be highly malleable since they can easily be molded according to the requirements of the dominant class and power structure of the society; here it happens to be the patriarchy of nineteenth-century India. However, when Deeti is saved from the pyre, she decides to marry Kalua in order to break off with the past and starts a new garhasthya life, a real conjugal life. While according to the Hindu religious rhetoric it was unthinkable that a widow could remarry and begin her life anew, though men were spared from such restrictions [7], Deeti flouts such religious rules not only through her remarriage and dream of a new life but also through her rejection of the insurmountable caste boundaries in marrying a low caste man. Therefore, Deeti's near self-sacrifice as sati in the novel acts as a phase of revelation and resuscitation, having gone through which she becomes aware of the need to constitute oneself as a conscious subject. Like the practice of self-immolation itself, which has been regarded, as Spivak has shown, as a "passage celebrating the entry of adorned wives into a dwelling place" ([16], p. 304), Deeti's being a part of the custom of sati also clears a passage for her to know about her own desire and her consciousness of being.

However, the ritual of sati for Deeti involves a series of actions which negate the dominant perception of women as objects in society. It acts as a method which enables Deeti to have a closer look at life and its true meaning, which has hitherto been mystified by social and cultural laws. According to Donald E Hall, the understanding of the subjectivity of an individual depends on a detailed examination of how conceptions of the self of the person "have metamorphosed over time with reference, and in response to [...] a host of newly recognizable/bigotries, social inequities, and hypocrisies" ([38], p. 40). The ritual of sati, however, provides Deeti with a sense of selfhood which now empowers her to see through the constrictive rules and hypocrisy of a patriarchal society. In the process, as a result, a consciousness arises which aims to take hold of the reign of her life, feelings and judgments which is further evinced in the delineation of her strong leadership qualities at sea. After their escape from the pyre, Deeti's and Kalua's downriver journey on the Ganga on a makeshift raft ends at the riverside township of Chhapra, where they enlist themselves as indentured laborers to be taken to the island of Mauritius by the slave ship. It is only among a group of migrants who share similar fates that she finds the necessity to implement the authority of her subjectivity, which attempts to organize the migrants' fragmented consciousness as well as make them aware of their self-respect. It is Deeti who makes the group realize the need to voice against their unjustified and humiliating marginalization by the powerful, which was heretofore regarded as the norm ([25], pp. 414-15). 
Nonetheless, Margaret Fuller in Woman in the Nineteenth Century (1845) exhorted that in order to achieve independent selfhood or subjectivity women should "leave off asking [men] and being influenced by them, but retire within themselves, and explore the ground-work of life till they find their peculiar secret" (qtd. in Hall [38], p. 43). However, the role that Deeti is seen to play on the ship not only manifests her independent selfhood but also inspires others to explore their own sense of being. Thus she is often seen as safeguarding frivolous migrant women from the lustful glances of male laborers ([25], p. 354), arranging marriages among the laborers even on the ship ([25], p. 441), arbitrating in disputes between the migrants and the guards of the ship ([25], p. 414) or settling almost every problem as a chieftain of the migrants, who under her authoritative management develop a form of familial relationship among them. Moreover, her fervor for the elevation of the spirit of the marginalized group to that of a powerful entity transforms her almost into a messiah for all in the group ([25], p. 430).

Nonetheless, it is also on the ship itself we find how her newly-acquired subjectivity, in the form of her remarriage and her decision to start her life anew, receives repudiation. Remarriage for widows of high castes, however, was forbidden since it was perceived as the defilement of the purity of their social status ([27], p. 468). Nonetheless, Deeti's escape and refusal of being a sati is now regarded as an idea that only a prostitute can cherish. This belief, however, is underpinned by a particular physical feature uncommon among women in Ghazipur. She possesses light grey eyes instead of the "normal" black eyes of Indian women, which gives her a look of a "chudaliya", a witch, to the little children and the other residents of her village. That she herself dislikes this different hue of her eyes is evident in her expressing relief at her daughter's having possessed the usual black eyes ([25], p. 5). Later in the novel, when she faces a near rape on the slave ship by an uncle, Bhyro Singh, one of her in-laws, who happens to be a Subedar on the Ibis, it is claimed that the different color of her eyes has always indicated that she is fit to be a prostitute rather than a homespun wife, and therefore, it is no crime at all to violate her. She, no more a member of the family of her in-laws, is now a religious and social perpetrator who should be punished and ostracized for showing disrespect to the family's reputation as a sati holder:

The grey eyes; I [Bhyro Singh] remember them, filled with witchery. The eyes of a chudail, some people thought—but I always said, no, those are the eyes of a whore [...]. Acknowledge a tie with a woman like you? A whore who's run away with a filth-sweeper? An overheated bitch who's brought shame on her family, her village, her in-laws? ([25], p. 476)

However, this unusual feature of Deeti's eyes becomes a symbol which indicates, for the rural Indian patriarchs, the justification of crossing the boundary between right and wrong. Sea of Poppies contextualizes the ideology maintained by the East of associating grey eyes, mostly found in the West, with debauchery, prostitution, and licentiousness [39]. Therefore, it becomes evident that the preservationist view of the East not only aims to preserve its purity through the observance of its ethnic religious practices such as sati ([16], p. 303) but also attempts to eliminate everything that appears foreign to its culture. Critics such as Nandy have reasoned it out thus:

Groups rendered psychologically marginal by their exposure to Western impact [...] had come under pressure to demonstrate, to others as well as to themselves, their ritual purity 
and allegiance to traditional high culture. To many of them sati became an important proof of their conformity to older norms at a time when these norms had become shaky within. (qtd. in Spivak [16], p. 298)

Major corroborates such views and argues that sati is represented "as an ideal for Hindu womanhood at a time when 'traditional' values are increasingly being eroded by feminist/liberal sensibilities" ([9], p. 785). Besides, sati became a symbol for Indian nationalism and as a measure of last resort of a failed nation ([21], p. 42). Therefore, the act of violence against "brown women" by "brown men", to borrow the concept from Spivak's disquisition, needs to be considered in the context of the East's preservationist approach towards its purity. Deeti's near violation by a male of her family-in-laws is actually an instance of rejecting or destroying the Western values which manifest themselves, as perceived by the East, both in the incident of Deeti's escape from the pyre and in the feature of her grey eyes. It can be extrapolated, therefore, that in order to reveal its own prejudiced intolerance of Western values and their impact on society, the East approves violence against its women and attempts to preserve the purity of society, of which women constitute a considerable part.

It is not surprising, therefore, that the society which views women as objects which should be possessed and utilized by men cannot accept women's existence as a separate entity and thereby maligns her if she wishes to cross the limit of social norms set by patriarchy [7]. However, Deeti's decision, which is governed by her recently acquired self-consciousness and subjectivity, to move her life forward, is mostly understood, more than self-will, as an effort to nullify patriarchal rhetoric of rules, which also at times take the form of religion. Thus the attempted rape on the slave ship is a direct consequence of Deeti's not being able to be a sati and therefore bring so-called honor and money for the family, and of her decision to lead her life on her own, which is certainly unacceptable to the faithful observers of religion and patriarchy. Deeti, meanwhile, was unable to relegate herself to the lower strata of the society and attempted to find solace on the pyre of her dead husband. After the incident of sati, a transformed Deeti starts giving primacy to her own self, her own desire over her family's honor and society's expectations. She herself proposes to get married to Kalua as she believes that her own upper-caste identity has burnt to ashes in her pyre. The pyre which is prepared for her transformation from human life into the life of a deity, in reality transforms her from being an object into a self-conscious woman, who, unlike a Hindu widow, knows the way to start a new life:

$[$ S]he $[\ldots]$ was free now to create a new destiny as she willed, with whom she choose - and she knew that it was with Kalua that this life would be lived, until another death claimed the body that he had torn from the flames. ([25], p. 178)

Therefore, it can be assumed that the process of the cult of sati paves a way for Deeti to reject the notions of the supremacy of class, caste, religion and gender over human life itself. In order to preserve her chastity and dignity, she appears to conform to one of the categories, the religious cult of sati, to exercise her control over her life. Nonetheless, when Deeti's subjective resolution to ride the pyre is misunderstood as an expression of her devotion to her husband, it receives huge acclamation from society, but when she is saved by a low caste man and later discovered unrepentant for not being able to die, her purpose of immolation receives condemnation and is regarded as an act of transgressing the boundary set for Hindu widows, which results in her threatened rape on the ship at a time when she feels she has already severed all ties with her past. 


\section{Conclusions}

The practice of sati in Sea of Poppies hardly appears as a superstitious and cruel ritual of murder since Deeti's act of attempted sati cannot be deemed as an exertion of religious stranglehold on a Hindu widow. The article has shown how the novel sidelines the polarizing beliefs of the West that Indian women, either physically forced by society or psychologically coerced by religion, embrace the cult of sati. It also negates the East's explication of the cult of sati as a purely religious activity that reflects women's loyalty and devotion to their husbands and religion. However, Deeti, as has been explicated above, is neither a staunch observer of religion who, motivated by religious rules, intends to sacrifice herself on the fire denying her own individual existence after her husband's death nor is she a passive victim of a diabolical plot hatched up by her in-laws. Rather it is argued that, for Deeti, the rhetoric and ritual of the cult of sati serve as a means by which she acquires subjectivity and authority over the course of her life, which also aid in the formation of her consciousness that nullifies the gender-restrictive norms of a colonized society.

Thus, the article has established the argument that in Sea of Poppies the woman who undertakes the ritual of sati cannot simply be reduced to an object of sympathy, and also, at the same time, she should not be viewed as the stalwart follower or epitome of the Hindu religious, cultural and social values who should be worshipped as a deity by the East. Rather, Ghosh points out the ways the victims of marginalization in society exert their self-will over their own lives under the guise of religion and cultural legacy. Instead of merely castigating the act of sati as a criminal Hindu ritual, Sea of Poppies delves deeply into the entrenched social and cultural discriminatory attitudes towards women in India and shows the ways constrictive rituals of religion, the very basis of the practice of sati as well as of Indian society and culture, serve as a ploy, which, instead of perpetrating violence, confers a subjective entity on the sati that can even subvert the constrictive norms of a colonized society.

\section{Acknowledgments}

I am greatly indebted to the two anonymous reviewers for their insightful comments on the article. I would like to extend my gratitude to Jopi Nyman from the University of Eastern Finland for his helpful suggestions on the article. I wish to thank Anupama Mohan from Presidency University, Kolkata for her helpful comments on an earlier draft of the paper. I would like to thank The Finnish Cultural Foundation for the funding support that has made this research possible.

\section{Conflict of Interest}

The author declares no conflict of interest.

\section{References and Notes}

1. For general discussion on Roop Kanwar case and similar incidents in India, see, for instance, Mala Sen. Death by Fire: Sati, Dowry Death and Infanticide in Modern India. London: Weidenfeld and Nicolson, 2001.

2. See Oldenburg for the explication of Roop Kanwar's immolation from feminist perspectives (Veena Talwar Oldenburg. "The Roop Kanwar case: Feminist Responses”. In Sati, the Blessing 
and the Curse. Edited by John Stratton Hawley. New York: Oxford University Press, 1994, pp. 101-30).

3. Andrea Major. "Self-determined sacrifices? Victimhood and volition in British constructions of sati in Rajput states, 1830-60." History and Anthropology 17 (2006): 313-25.

4. Sakuntala Narasimhan. Sati: A Study of Widow Burning in India. New Delhi: Harper Collins Publishers India, 1998.

5. Francine Pickup, Suzanne Williams, and Caroline Sweetman. Ending Violence against Women: A Challenge for Development and Humanitarian Work. Oxford: Oxfam GB, 2001.

6. Arvind Sharma. Sati: Historical and Phenomenological Essays. Delhi: Motilal Banarsidass, 1988.

7. Anand A.Yang. "Whose sati?: Widow burning in early 19th century India." Journal of Women's History 1 (1989): 8-33.

8. Lata Mani. "Production of an official discourse on 'Sati' in early nineteenth century Bengal." Economic and Political Weekly 21 (1986): 32-40.

9. Andrea Major. "A question of rites? Perspectives on the colonial encounter with sati." History Compass 4 (2006): 780-99.

10. Lata Mani. Contentious Traditions: The Debate on Sati in Colonial India, 1780-1833. Berkeley: University of California Press, 1998.

11. Paul B. Courtright. "The iconographies of sati." In Sati, the Blessing and the Curse. Edited by John Stratton Hawley. New York: Oxford University Press, 1994, pp. 27-49.

12. Ashis Nandy. "Sati as profit versus sati as a spectacle: The public debate on Roop Kanwar's death". In Sati, the Blessing and the Curse. Edited by John Stratton Hawley. New York: Oxford University Press, 1994, pp. 131-49.

13. Nandini Bhattacharyya-Panda. "Women in the Śāstric tradition: Colonialism, law, and violence." In The Blackwell Companion to Religion and Violence. Edited by Andrew R. Murphy. Oxford: Wiley-Blackwell, 2011, pp. 389-405.

14. Ruth Bacchus. "Sati and performativity". Australian Feminist Studies 28 (2013): 155-76.

15. Nandini Bhattacharyya-Panda. Appropriation and Invention of Tradition: The East India Company and Hindu Law in Early Colonial Bengal. New Delhi: Oxford University Press, 2008.

16. Gayatri Spivak. "Can the subaltern speak?" In Marxism and the Interpretation of Culture. Edited by Cary Nelson, Lawrence Grossberg. Champaign: University of Illinois Press, 1988, pp. 271-313.

17. Ania Loomba. "Dead women tell no tales: Issues of female subjectivity, subaltern agency and tradition in colonial and post-colonial writings on widow immolation in India." History Workshop 36 (1993): 209-27.

18. Ania Loomba. Colonialism/Postcolonialism. London: Routledge, 2002.

19. Chitra Sankaran, ed. History, Narrative, and Testimony in Amitav Ghosh's Fiction. Albany: State University of New York Press, 2012.

20. Anant Sadashiv Altekar. The Position of Women in Hindu Civilization. Delhi: Motilal Banarsidass, 1961. Altekar offers a detailed discussion on the rhetorical significance of the practice of sati and its role in the joyous afterlife of a Hindu widow.

21. Tanika Sarkar. Hindu Wife, Hindu Nation: Community, Religion, and Cultural Nationalism. Champaign: Indiana University Press, 2001. 
22. Pamela S. Johnson, and Jennifer A. Johnson. "The oppression of women in India." Violence against Women 7 (2001): 1051-68. Johnson and Johnson have claimed that the preference for male child is prevalent in India which also results in infanticide and the disparities in sex-ratio.

23. Amrita Chhachhi. "The state, religious fundamentalism and women trends in south Asia." Economic and Political Weekly 24 (1989): 20-30. Chhachhi has claimed that son-preference in Indian society is correlated with "labour force" and not with religion.

24. Daniel J.R. Grey. "Creating the 'Problem Hindu': Sati, Thuggee and female infanticide in India, 1800-60." Gender \& History 25 (2013): 498-510. Grey observes that the birth of a girl child in Indian society is discouraged since it portrays a huge expenditure in the form of the popular social practice of dowry during her marriage.

25. Amitav Ghosh. Sea of Poppies, 2nd ed. New Delhi: Penguin Books, 2009.

26. Catherine Weinberger-Thomas. Ashes of Immortality: Window Burning in India. Chicago: University of Chicago Press, 1999.

27. Dorothy Stein. "Burning widows, burning brides: The perils of daughterhood in India." Pacific Affairs 61(1988): 465-85.

28. Lindsey Harlan. Religion and Rajput Women: The Ethic of Protection in Contemporary Narratives. Berkeley: University of California Press, 1992.

29. Andrea Major. "The burning of Sampati Kuer: Sati and the politics of imperialism, nationalism and revivalism in 1920s India." Gender \& History 20 (2008): 228-47.

30. Referring to a twentieth-century incident of sati of Sampati Kuer, Major argues that child brides or teenage brides "with no prospects or protector" were easy prey for constrictive Hindu social practices ([29] p. 239).

31. Yang [7] has pointed out that the district of Ghazipur and Gorakhpur in Banaras had the highest incidence of sati. He informs that between the years 1815-1826 there were, on average, 30 incidents of sati per year in Ghazipur.

32. Though sati was prohibited in 1829, the glorification of the custom was not outlawed. Major remarks that even three years after the rite's prohibition, the local government in Calcutta would allow the building of temples at the site of sati in 1832 ([29] p. 238).

33. Radha Kumar. The History of Doing: An Illustrated Account of Movements for Women's Rights and Feminism in India, 1800-1900. London: Verso, 1993.

34. Jeanette Herman. "Men and women of feeling: Conventions of sensibility and sentimentality in the sati debate and Mainwaring's The Suttee." Comparative Literature Studies 42 (2005): 223-63.

35. Similar view has been expressed by Mani who claims that in the colonial discourse on sati women constituted only the periphery of it since for the British the promulgation of the anti-sati law and therefore rescuing the sati appeared only as part of the mission of civilizing the natives and thus the woman as a sati and her suffering were always sidelined in the discussion on the practice (Lata Mani. "Contentious traditions: The debate on sati in colonial India." Cultural Critique 7 (1987): 119-56).

36. Major claims that the British policy of religious toleration in India depended in part "on enlightenment ideas about individual rights to religious expression" ([9], p. 788).

37. Ramusack focuses on the common bracketing of women and shudras and their lower status in the hierarchical order of Hindu caste system. Barbara N Ramusack. "Women in south and southeast 
Asia.” In Women in Asia. Edited by Barbara N. Ramusack and Sharon L Sievers. Bloomington: Organization of American Historians, 1988, pp. 3-144.

38. Donald E. Hall. Subjectivity. New York: Routledge, 2004.

39. Deeti's piercing, "unusual" and "colourless" eyes that "made her seem at once blind and all-seeing" have much been emphasized throughout the novel ([25], p. 5). However, many French characters in the novel have been represented as in possession of grey eyes. Therefore, Deeti's uncommon grey eyes symbolize her transgression of the ritualistic boundary of the East.

(C) 2014 by the author; licensee MDPI, Basel, Switzerland. This article is an open access article distributed under the terms and conditions of the Creative Commons Attribution license (http://creativecommons.org/licenses/by/3.0/). 